\title{
Innleiðing rafrænna skjalastjórnunarkerfa samkvæmt átta prepum Kotters; viðhorf íslenskra skjalastjóra
}

\author{
Magnea Davíðsdóttir, Jóhanna Gunnlaugsdóttir og Gylfi Dalmann \\ Aðalsteinsson ${ }^{1}$
}

\section{Ágrip}

Skjalastjórnun er einn peirra stjórnunarpátta sem stuðla að skipulegri stjórnun fyrirtækja og stofnana pannig að starfsemin sé rekin á hagkvæman og ábyrgan hátt. Án skjalastjórnunar er hætta á að skjöl glatist og eyður myndist í rekstrarsamfellu fyrirtækisins. Pá styður skjalastjórnun við stjórnun áhættu með tilliti til upplýsingaöryggis, veitir frumkvæði í gæðaog umhverfismálum, gerir auðveldara að mæta kröfum löggjafar og reglugerða, óskum viðskiptavina og pörfum starfsfólks. Aukin hætta er á að skjöl rati í rangar hendur eða eyðileggist sé kerfisbundin skjalastjórnun ekki fyrir hendi auk pess sem hún stuðlar að gegnsæi og rekjanleika í rekstrinum. Á síðustu árum hefur mikið verið hugað að stjórnun rafrænna skjala innan stofnana og fyrirtækja. Áhersla hefur verið lögð á kerfisbundna vistun peirra með pað fyrir augum að bæta pjónustu og rekstur. Skjalastjórnun sem starfsgrein er tiltölulega ný af nálinni og hugtakið kom ekki til sögunnar fyrr en upp úr miðri síðustu öld. Sú tækni sem nefnd er rafrænt skjalastjórnunarkerfi (RSSK) auðveldar að stýra upplýsinga- og skjalaflæði innan fyrirtækja og stofnana. Áhersla á vandaða og gegnsæja stjórnsýslu sem og krafa almennings um aðgengi að opinberum gögnum hefur skapað nauðsyn pess að stofnanir taki í notkun RSSK. Gagnagrunnar svo sem RSSK stuðla að altækri og hagkvæmri skjalastjórnun. En breytingar eins og að koma á skipulegri skjalastjórnun geta reynst erfiðar. Pessi rannsókn veitir innsýn í við̌horf og pátttöku skjalastjóra í pví breytingarferli sem innleiðing RSSK er. Spurningalisti var lagður fyrir íslenska skjalastjóra sem voru aðilar að Félagi um skjalastjórn og höfðu tekið pátt í að innleiða RSSK. Spurningalistinn innihélt m.a. 19 spurningar sem byggðu á hinum átta prepum Kotters varðandi innleiðingu breytinga. Helstu niðurstöður voru að skjalastjórar bera ekki fullt traust til æðstu stjórnenda til pess að viðhalda breytingum, millistjórnendur studdu innleiðinguna ekki sem skyldi en pað gerðu hins vegar æðstu stjórnendur. Skortur var á fræðslu og pjálfun til handa skjalastjórum vegna innleiðingarinnar. Um priðjungur skjalastjóra sagði að innleiðingin hefði mætt andstöðu meðal starfsmanna og um $40 \%$ upplifðu innleiðinguna sem tækifæri fremur en ógnun. Sama hlutfall skjalastjóra sagði að viðbrögð starfsmanna við innleiðingunni hefðu verið jákvæð. Loks benda niðurstöðurnar til pess að upplýsingamiðlun til starfsmanna hafi ekki verið

${ }^{1}$ Magnea Davíðsdóttir; MA, starfar sem skjalastjóri hjá Símanum. Dr. Jóhanna Gunnlaugsdóttir er prófessor við félags- og mannvísindadeild Háskóla Íslands. Gylfi Dalmann Aðalsteinsson er dósent við viðskiptafræðideild Háskóla Íslands. Höfundar pakka ritrýnum og ritstjóra fyrir gagnlegar ábendingar.

This work is licensed under a Creative Commons Attribution 4.0 License. 
nægilega góð. Til pess að yfirvinna andstöðu starfsmanna parf að virkja pá í breytingaferlinu, halda peim upplýstum um ferlið og umbuna peim fyrir að taka pátt í nýja kerfinu.

\begin{abstract}
Records management is one of the functions that contribute to more efficient and responsible management within organizations. Without records management there is a risk that documents get lost and gaps are being formed in the operations of the organization. It supports risk management with respect to information security, provides initiatives in quality management and environmental issues thus making it easier to meet demands of legislation and regulations as well as meeting the wishes of customers and the needs of employees. Without systematic records management there is an increased risk that records get into the wrong hands or get destroyed. In addition it promotes transparency and traceability in operations. In recent years the management of electronic records within organizations has been given a lot of thought. An emphasis has been placed on systematic capture of these records with the aim of improving both the service and the operations. Records management as a profession is relatively new. The concept did not come to the scene until in the middle of the 20th century. The technology which has been called electronic records management systems (ERMS) helps to manage information and flow of records within organizations. Emphasis on good and transparent governance as well as public demand for access to official records has created the need for organizations to implement ERMS. Data bases such as ERMS can promote total and efficient records management. Changes such as implementing systematic records management can prove to be difficult. This research provides insight into the views and participation of records managers in the change process of implementing ERMS. A questionnaire was sent to Icelandic records managers that were members of the Icelandic Records Management Association and had experience in implementing ERMS. The questionnaire contained 19 questions based on the Kotter's eight steps regarding the implementation of change. The main findings were that the records managers did not have full confidence that top management would preserve the change. Middle management did not fully support the implementation which, however, enjoyed the full support of top management. There was a lack in education and training for the records managers regarding the implementation process. About one third of the records managers said that the implementation had met with resistance among employees and $40 \%$ experienced the implementation as an opportunity rather than a threat. The same proportion of records managers said that the reaction of employees to the implementation was positive. Finally, the results indicate that the dissemination of information to employees during the implementation process was not sufficient. One of the key factors in dealing with employee resistance is to involve them in the change process, keep them informed and reward them for participating in the new system.
\end{abstract}

JEL flokkun: M15, M38

Lykilorð: Upplýsinga- og skjalastjórnun, rekstrarhagkvæmni, breytingastjórnun, innleiðingarferli, rafrænt skjalastjórnunarkerfi, RSSK 


\section{Inngangur}

Skjalastjórnun er mikilvæg í rekstri fyrirtækja og stofnana. Án hennar eru líkur á að upplýsingar og skjöl glatist og eyður myndist í rekstrarsamfellu fyrirtækisins. Skjalastjórnun stuðlar pannig að skipulegri stjórnun svo að starfsemin sé rekin á hagkvæmari hátt. Pá styður hún við stjórnun áhættu með tilliti til upplýsingaöryggis, veitir frumkvæði í gæða- og umhverfismálum, gerir auðveldara að mæta kröfum löggjafar og reglugerða svo og óskum viðskiptavina og pörfum starfsfólks. Aukin hætta er á að skjöl rati í rangar hendur eða eyðileggist sé kerfisbundin skjalastjórnun ekki fyrir hendi auk pess sem hún stuðlar að gegnsæi og rekjanleika í rekstrinum. Hún leiðir enn fremur til pess að verðmætum tíma starfsfólks sé síður varið í að leita að upplýsingum.

Pegar koma skal á skjalastjórnun innan skipulagsheildar getur reynst erfitt að breyta viðteknum venjum og verklagi sem fyrir er. Breytingar eins og að koma á skipulegri skjalastjórnun geta reynst erfiðar. Eitt af erfiðustu verkefnum stjórnenda er að hrinda breytingum í framkvæmd og helsta áskorunin felst í að breyta ákveðinni menningu og hegðun starfsmanna sem m.a. birtist í pví að innleiða nýtt vinnulag, nýja verkferla og ný vinnubrögð innan stofnana og fyrirtækja. Tilgangur greinarinnar er að kynna niðurstöður rannsóknar sem veitir innsýn í viðhorf og pátttöku skjalastjóra í pví breytingarferli sem innleiðing rafræns skjalastjórnunarkerfis (RSSK) er. Greinin er að hluta til byggð á stærri rannsókn sem gerð var 2010-2013 (Magnea Davíðsdóttir, 2013).

Við gerð rannsóknarinnar var stuðst við megindlega aðferðafræði. Rafrænn spurningalisti var lagður fyrir íslenska skjalastjóra sem voru aðilar að Félagi um skjalastjórn. Spurningalistinn byggði á hinum átta prepum Kotters (1996) varðandi innleiðingu breytinga. Rannsóknarspurningin snerist um hvert væri viðhorf íslenskra skjalastjóra, sem höfðu tekið pátt í innleiðingu RSSK, til innleiðingarferlisins. Enn fremur var menntunarstig skjalastjóra kannað og hversu lengi peir hefðu starfað við skjalastjórn. Pá var kannað hvort fram hefði farið parfagreining vegna innleiðingar RSSK og hvort skjalastjórar hefðu tekið pátt í peirri parfagreiningu. Loks var kannað hvort skjalastjórar hefðu tekið pátt í vali á RSSK.

Greinin skiptist í nokkra kafla. Í upphafi er gerð grein fyrir fræðilegum bakgrunni rannsóknarinnar og greint frá íslenskum og erlendum rannsóknum sem tengjast viðfangsefni hennar. Pví næst eru aðferðafræði rannsóknarinnar gerð skil og síðan fjallað um rannsóknina sjálfa í niðurstöðu- og umræðuköflum. Loks eru lokaorð sett fram.

\section{$2 \quad$ Fræðileg umfjöllun}

Skjalastjórnun (e. records management) er stjórnun skjala samkvæmt almennu hugmyndinni um lífshlaup skjals (e. records life cycle consept). Рað felur í sér að sérhvert skjal eigi sér ákveðið lífshlaup sem felst í sex stigum, p.e. myndun skjalsins, dreifingu pess, notkun, viðhaldi og eyðingu (Read og Ginn, 2011). Sum skjöl parf lögum samkvæmt að varðveita varanlega og pá verður lokastigið varanleg varðveisla.

Hagur er af kerfisbundinni skjalastjórnun eins og fyrr segir en skjöl og upplýsingar eru sönnun um starfsemina og varðveita sögu vinnustaðarins til framtíðar. Stjórnun áhættu, upplýsingaöryggi og neyðaráætlun eru mikilvægir hlutar skjalastjórnunar og hún styður staðal um upplýsingatækni og stjórnkerfi upplýsingaöryggis (Staðlaráð Íslands, 2006). Skipuleg skjalastjórnun gerir kleift að uppfylla kröfur gæða- og umhverfisstaðla (sjá til dæmis Staðlaráð Íslands, 2004; 2008) og rannsóknir hér og erlendis sýna að ágallar í skjalastjórnun eru 
helsta ástæða pess að vottun fæst ekki í fyrstu tilraun. Pá er misbrestur í skjalastjórnun einnig tíðasta athugasemdin við reglulegt eftirlit vottunarstofu (Gunnlaugsdóttir, 2012).

Skjöl geta einnig veitt stuðning við vörn í málaferlum sem beinast gegn starfseminni og iðulega hefur skipuleg skjalastjórnun komið sér vel pegar vernda á hagsmuni fyrirtækis eða viðskiptavina og rétt starfsmanna. Skjöl sem fullnægja kröfum skjalastjórnunar, p.e.a.s. eru skipulögð og aðgengileg, geta verið sönnun pess аð farið hafi verið að lögum, reglugerðum, stjórnarfyrirmælum og siðareglum. Pá auðveldar hún endurskoðun og eftirlit. Skjalastjórnun ætti að greiða fyrir hnökralausri pjónustu samkvæmt viðskiptasamningum og vinnustaðurinn yrði líklegri til pess að skapa áhugaverð störf og starfsumhverfi enda færi orkan í að byggja upp og veita góða pjónustu í stað leitar að upplýsingum og að slökkva sinuelda (Gunnlaugsdóttir, 2002). Enn fremur skipta skjöl og skjalastjórnun máli við áreiðanleikakannanir t.d. í sambandi við kaup, sölu og sameiningu fyrirtækja og pegar fyrirtæki eru að undirbúa skráningu á markað.

Á síðustu árum hefur mikið verið hugað að stjórnun rafrænna skjala innan stofnana og fyrirtækja. Áhersla hefur verið lögð á kerfisbundna vistun peirra með pað fyrir augum að bæta pjónustu og rekstur skipulagsheilda (Alfa Kristjánsdóttir, 2000). Skjalastjórnun sem starfsgrein er tiltölulega ný af nálinni og hugtakið kom ekki til sögunnar fyrr en upp úr miðri síðustu öld (Jóhanna Gunnlaugsdóttir, 2006). Skilgreining Félags um skjalastjórn á hugtakinu er eftirfarandi:

\begin{abstract}
Skjalastjórn er kerfisbundin stjórn á skjölum frá pví að pau verða til í stofnun eða fyrirtæki eða berast að og par til peim er eytt eða komið fyrir í varanlegri geymslu. Skjalastjórn felur í sér flokkun og merkingu skjala, dreifingu, vistun, endurheimt, gerð̈örefnis, enn fremur stjórn á framleiðslu og notkun eyðublaða, skýrslna, gerð geymslu- og öryggisáætlana og fræðslu starfsfólks í stofnunum um skjalamál (Félag um skjalastjórn, 2008).
\end{abstract}

Skilgreiningin kom fyrst fram hérlendis árið 1988 (Kristín H. Pétursdóttir) og á upphaf sitt að rekja til Samtaka ástralskra skjalastjóra (RMAA). Skilgreiningin hefur elst vel og segja má að hún sé enn í fullu gildi meðal peirra sem starfa á vettvangi skjalastjórnunar (Ingibjörg Hallbjörnsdóttir, 2007).

Jóhanna Gunnlaugsdóttir og Kristín H. Pétursdóttir (1998) tilgreina að skjalastjórnun eigi að tryggja að hægt sé að finna skjöl fljótt og örugglega pegar á parf að halda og auka pannig hagkvæmni í rekstri skipulagsheilda. Enn fremur að skjalastjórnun sé ætlað að tryggja að skjöl hvorki glatist, skemmist né komist í hendur óviðkomandi aðila. Pá á hún að koma í veg fyrir að ónauðsynlegur pappír og upplýsingar í annars konar formi safnist fyrir á vinnustöðum og í geymslum og sömuleiðis að fyrirbyggja ótímabæra eyðingu skjala.

Í skjalastjórnunarstaðlinum ÍST/ISO 15489:2001 er hugtakið skjalastjórnun skilgreint sem pað „,stjórnunarsvið sem ber ábyrgð á skilvirkri og kerfisbundinni stýringu á myndun skjals, móttöku, skjalahaldi, notkun og umráðum, p. á m. ferlum til að fanga og viðhalda vitnisburði og upplýsingum um starfsemi og viðskipti í formi skjala“ (Staðlaráð Íslands, 2005, bls. 12). Staðallinn gerir greinarmun á skjalastjórnun og skjalavörslu en par er lögð áhersla á að hann veiti leiðsögn um skjalastjórnun skipulagsheilda par sem skjöl eru mynduð en nái ekki til skjalavörslu og varðveislu skjala í varðveislustofnunum (Staðlaráð Íslands, 2005).

Saffady (2011) gerir einnig greinarmun á skjalavörslu og skjalastjórnun. Hann bendir á að meginviðfangsefni skjalastjórnunar snúist um að nýta skráðar upplýsingar á hverjum tíma starfseminni til hagsbóta - greinin pjóni pannig starfsmönnum viðkomandi stofnunar eða 
fyrirtækis sem parfnist upplýsinga til pess að sinna störfum sínum. Að hans mati er viðfangsefni skjalavörslu hins vegar að varðveita upplýsingar til framtíðar og tilgangurinn að ná menningarlegum, sögulegum, fræðilegum og rannsóknartengdum markmiðum.

Sú tækni sem nefnd er rafrænt skjalastjórnunarkerfi (RSSK) auðveldar að stýra upplýsinga- og skjalaflæði innan stofnunar. Áhersla á vandaða og gegnsæja stjórnsýslu sem og krafa almennings um aðgengi að opinberum gögnum hefur skapað nauðsyn pess að stofnanir taki RSSK í notkun. Einkafyrirtæki hafa tekið RSSK í pjónustu sína í vaxandi mæli með pað fyrir augum að auka hagkvæmni í rekstrinum og skilvirkni og bæta pjónustu við viðskiptavini. Rafræn skjalastjórnun og kerfi leiða til hagkvæmni í húsnæðis- og geymslukostnaði en slíkur sparnaður getur numið háum fjárhæðum (Gunnlaugsdóttir, 2002).

Gagnagrunnar eins og RSSK stuðla að altækri og hagkvæmri skjalastjórnun. Með pví er átt við að öll skjöl sem eiga að vera í gagnagrunninum séu fönguð kerfisbundið, flokkuð, skráð og vistuð skipulega í samræmi við upplýsingafræðilegar aðferðir. Með notkun RSSK á að vera hægt að nálgast skjöl hvenær og hvaðan sem er með tengingum um víðnet. Um leið bjóða slík kerfi upp á aðgangsstýringu pannig að einungis tilteknir starfsmenn hafa aðgang að tilteknum upplýsingum. Pá auðvelda RSSK útgáfustýringu á skjölum enda gerir hugbúnaðurinn kleift að bera kennsl á nýjustu útgáfu skjala. Kerfin gera enn fremur mögulegt að stýra grisjun og eyðingu peirra skjala sem eyða má og stuðla að varanlegri varðveislu tiltekinna skjala. Geymslutími og varðveisla upplýsinga miðast við ákveðnar reglur sem byggjast á pörfum stofnunarinnar eða fyrirtækisins og peim lögum og reglugerðum sem peim ber að fara eftir. Á pann hátt gera RSSK fyrirtækjum og stofnunum auðveldara um vik að uppfylla lagakröfur (Jóhanna Gunnlaugsdóttir, 2007; Kibby, 2005; Saffady, 2011).

Í staðlinum ÍST/ISO 15489:2001 (Staðlaráð Íslands, 2005) kemur fram að skilgreina purfi ábyrgðarsvið og boðvald og kveðið er á um sérstaka forystuábyrgð og forsvarsaðila pegar kemur að skjalastjórnun og RSSK. Par er jafnframt lögð áhersla á að sérfræðingar í skjalastjórnun beri ábyrgð á öllu pví sem viðkemur fagsviðinu m.a. hönnun, innleiðingu og viðhaldi RSSK og aðgerðum í peim svo og pjálfun notenda kerfanna. Í staðlinum er einnig kveðið á um ábyrgð og stuðning framkvæmdastjóra skipulagsheilda hvað skjalamál varðar (Staðlaráð Íslands, 2005).

Stjórnendur og embættismenn gera sér í auknum mæli grein fyrir mikilvægi pess að koma á upplýsinga- og skjalastjórnun og ríkari kröfur eru gerðar í lögum og reglugerðum um skjalastjórnun innan stofnana og fyrirtækja. Grundvallaratriði pess að ná fram kerfisbundinni skjalastjórnun er að ráða hæfa starfsmenn sem hafa aflað sér góðrar pekkingar, menntunar og reynslu á sviðinu (Ingveldur Tryggvadóttir, 2003). Áströlsku fræðimennirnir Goldschmidt, Joseph og Debowski (2012) leggja áherslu á skjalastjórar séu með í ráðum pegar verið er að hanna og taka RSSK í notkun.

Skilvirk innleiðing er grundvöllur pess að RSSK nýtist á hagkvæman hátt. Til pess að svo megi verða purfa allir peir starfsmenn sem á annað borð eiga að vinna í kerfinu að gera slíkt og pað á samræmdan máta eftir viðurkenndum aðferðum og vinnulagi sem tíðkast innan skipulagsheildarinnar (Jóhanna Gunnlaugsdóttir, 2007).

Pegar breska samkeppnisstofnunin, Competition Commission, tók að innleiða RSSK árið 2002 var litið á verkefnið sem meiriháttar breytingarverkefni. Haft var eftir stjórnanda verkefnisins að pótt verið væri að innleiða nýja tækni snerist verkefnið fyrst og fremst um að leiða og stýra breytingum (Kibby, 2005). Innleiðing á nýjum hugbúnaði eins og RSSK breytir vinnubrögðum og venjum starfsfólks umtalsvert. Af pví leiðir að mikilvægt er að nýta aðferðafræði breytingarstjórnunar svo að innleiðingin megi heppnast. 
Breytingar eru óhjákvæmilegur páttur í starfsemi skipulagsheilda. Pær snúast gjarnan um fólk. Stöðugar framfarir og frampróun krefjast breytinga. Kotter $(1996,2005)$ hefur fjallað um breytingar. Breytingar geta orðið á starfsemi skipulagsheildarinnar sem beinast m.a. að hegðun starfsmanna, breyttu vinnulagi og breytingu á hefðum og venjum (Bridges, 2003; Cummings og Worley, 2005; Galpin, 1996; Hiatt, 2006). Breytingin getur tekið til endurhönnunar, endurskipulagningar, niðurskurðar, samruna, gæðastarfs eða umbreytingar á menningu. Samkvæmt Schein (2004) geta meiriháttar breytingar innan skipulagsheildar haft mikil áhrif á starfsfólk par sem pær snúa að viðteknu vinnufyrirkomulagi, venjum og hefðum auk ríkjandi gilda og vinnustaðarmenningar. Enn fremur getur andstaða orðið til í hugum starfsfólks par sem pað gæti átt á hættu að missa spón úr aski sínum og staða pess innan skipulagsheildarinnar kynni að breytast. Martin og Fellenz (2010) nefna sem dæmi um ástæðu andstöðu gegn breytingum misskilning, ónógar upplýsingar, slæma reynslu af öðrum breytingum, minna umboð til athafna, hræðslu við að gera mistök og að ávinningur af breytingunum sé ekki sýnilegur. Pá benda peir á að andstaðan geti myndast telji starfsfólk breytingarnar ógnun af einhverju tagi.

Segja má að kenningar Lewin (1947) leggi grunninn að fræðilegri umræðu um breytingar. Hann skoðaði breytingar m.t.t. atferlis einstaklinga og jafnvægisins sem skipulagsheildir hafa tilhneigingu til pess að leita í. Framkvæmd og innleiðing breytinga er eitt af erfiðari viðfangsefnum stjórnenda. Einkum getur reynst erfitt að breyta vinnustaðarmenningu og fá starfsfólk til pess að breyta fyrri hegðun. Breyting snýst um margvíslega pætti. Frá sjónarhorni einstaklinga kynni hún að snúast um breytt vinnulag eða hegðun en frá sjónarhorni stjórnanda gæti hún varðað samruna, yfirtöku, tæknibreytingar, breytingar í skipuriti eða ný og breytt verkefni (Armstrong, 2012; Carnall, 2003; Palmer, Dunford og Akin, 2009, Senior og Fleming, 2006).

Breytingarstjórnun fjallar um skilvirka og markvissa innleiðingu breytinga hjá skipulagsheildum og hvernig stýra megi breytingarferlinu pannig að hámarksárangur náist (Drucker, 2001). Bridges (2003) nálgast breytingarstjórnun með hliðsjón af mannlegum páttum og bendir á að breytingar snúist um að aðstoða starfsmenn við að ganga í gegnum eins konar umbreytingu (e. transition). Í umbreytingarferlinu segir starfsfólk skilið við eldri siði og venjur, tekst á við eins konar söknuð eða missi og tekst á við hið ópekkta áður en nýtt upphaf eða nýtt tímabil hefst. Flestar skilgreiningar á hugtakinu breytingarstjórnun innan skipulagsheilda eiga pað sammerkt að pær skírskota jafnan til leiða eða aðferða sem breyta viðteknum venjum, fyrirkomulagi, verklagi eða hefðum yfir í æskilegt framtíðarfyrirkomulag.

Átta prepa líkanið (Kotter 1996; Kotter og Cohen, 2002) nær yfir tiltekið vinnulag við að innleiða breytingar. Lögð er áhersla á að sífellt sé hugað að pessu breytingarlíkani, stjórnendur skipulagsheilda séu meðvitaðir um pað og sjái til pess að skapa pá menningu sem getur tekið á móti breytingum. Prepin átta (Kotter, 1996) sem um ræðir eru eftirfarandi:

1. Skynja pörfina fyrir breytingar (e. establishing a sense of urgency).

2. Mynda leiðbeinandi bandalag (e. creating the guiding coalition).

3. Skapa skýra framtíðarsýn og markmið (e. developing a vision and strategy).

4. Miðla breytingarsýninni (e. communicating the change vision).

5. Tryggja víðtæka valddreifingu eða umboð til athafna (e. empower broad based action).

6. Fagna áföngum að takmarkinu (e. generating short term wins).

7. Meta árangur og móta nýjar breytingar (e. consolidating gains and producing more change).

8. Festa breytingar í menningunni (e. anchoring new approaches in the culture) 
Kotter (1996) telur eina helstu ástæðu pess að breytingar mistakist vera að stjórnendur virðist oft keyra pær áfram án pess að koma hugmyndinni á framfæri eða markaðssetja hana sem mikilvæga fyrir skipulagsheildina. Рað verði til pess að skilja starfsmenn eftir í lausu lofti. Pá bendir hann á að oft sé tilteknum prepum sleppt, stjórnendur stytti sér leið, sem hafi í för með sér að peir verði stundum fyrir bakslagi eða lendi í ógöngum. Helsta áskorunin og kjarninn í breytingarferlinu er að breyta hegðun starfsfólksins sjálfs innan skipulagsheildarinnar. Samkvæmt Kotter og Cohen (2002) hefur átta prepa líkanið um breytingar skilað miklum árangri í áranna rás. Peir halda pví fram að lykillinn að góðum árangri felist í pví hversu mikil áhersla sé lögð á að höfða til tilfinninga starfsfólks í sjálfu ferlinu. Pá benda peir á að sýn og stefna, menning, ferlar og skipulag séu mikilvæg atriði varðandi innleiðingu breytinga hjá skipulagsheildum en enn mikilvægara sé að ná fram breytingum á atferli og hegðun starfsfólks.

Kotter og Cohen (2002) leggja áherslu á breytingarvilja (e. change readiness). Til pess að kanna hann tiltaka peir fjóra pætti sem hafa parf að leiðarljósi í breytingum. (1) Ekki er gerlegt að hefja raunverulegar breytingar án pess að hafa raunsæja mynd af ástandi skipulagsheildarinnar. Ef hægt á að vera að kanna breytingarviljann purfa réttar upplýsingar um pað sem er að gerast hjá skipulagsheildinni að liggja fyrir. (2) Koma parf auga á hindranir og sér í lagi pær sem snúast um menninguna. Pví fyrr sem stjórnendur skilja menninguna peim mun líklegra er að innleiðing breytinga gangi vel fyrir sig. (3) Máli skiptir að ræða við pað starfsfólk sem er næst vettvangi og vinnur að peim verkefnum sem breytingarnar ná yfir. Pað starfsfólk veit meira en stjórnendur um vandamálin sem blasa við og hvernig best er að taka á peim og leysa. Pá pekkir pað fremur en stjórnendurnir hinar raunverulegar parfir. (4) Nauðsynlegt er að stjórnendur séu tilbúnir til pess að taka með í reikninginn áætlanir vegna aðstæðna sem skapast við andstöðu starfsfólks gegn tilteknum breytingum. Skipt getur sköpum að styðjast við áætlun sem felur í sér lausnir á pví hvernig eigi að yfirvinna andstöðu.

\section{Fyrri rannsóknir um notkun og innleiðingu rafrænna skjalastjórnunarkerfa}

Hér á landi eru ekki fyrir hendi rannsóknir sem fjalla beinlínis um hlutverk skjalastjóra við innleiðingu á rafrænum skjalastjórnunarkerfum (RSSK) en hægt er að finna nokkrar rannsóknir á sviði upplýsingafræða og opinberrar stjórnsýslu par sem fjallað er um skjalastjórnun og skjalastjóra. Jóhanna Gunnlaugsdóttir (2007) rannsakaði innleiðingu og notkun RSSK og var tilgangur rannsóknarinnar m.a. að kanna markmiðið með pví að innleiða RSSK, hvernig innleiðingunni væri háttað og tengsl milli innleiðingar og notkunar kerfanna. Rannsóknin leiddi m.a. í ljós að aðferðir breytingarstjórnunar ættu vel við pegar verið væri að innleiða upplýsingakerfi eins og RSSK. Jóhanna Gunnlaugsdóttir (2007) tiltekur ýmsa höfunda s.s. Beckhard (1969), Beckhard og Harris (1987), Kolb og Frohman (1970) og Kotter (1996) sem dregið hafa upp líkön að breytingarferlinu. Peir brjóti breytingarferlið gjarnan upp í tiltekna, afmarkaða pætti eða hluta. Líkön peirra voru aðlöguð með hliðsjón af reynslu og ráðgjöf við innleiðingu upplýsinga- og skjalastjórnunar og RSSK í skipulagsheildum. Segja má að fræðimenn skipti breytingarferlinu í prjá pætti: (1) Greiningu á pörfinni fyrir breytingar (Kotter, 1996), (2) að koma breytingunum á og (3) að viðhalda breytingunum. Síðasti pátturinn, varðveislustigið, er afar mikilvægur samkvæmt Lewin (1951) sem fjallar um mikilvægi pess að píða, hreyfa og frysta. Ein helsta niðurstaða Jóhönnu var sú að stuðningur stjórnenda væri lykilforsenda pess að innleiðingin gengi vel fyrir sig og í pví sambandi má nefna að millistjórnendur gegna auk pess jafnan lykilhlutverki í breytingum (Huy, 2001). Par sem stuðningur stjórnenda var mikill gekk innleiðingin jafnan vel fyrir sig. Stuðningur peirra fólst 
m.a. í hvatningu og umbun starfsfólks, áhuga stjórnendanna sjálfra á verkefninu, virkri pátttöku peirra í innleiðingunni og að vera góð fyrirmynd pegar kom að notkun kerfisins. Pátttaka starfsfólks var enn fremur mjög mikilvæg svo og fræðsla um mikilvægi skjalastjórnunar fyrir tiltekna stofnun eða fyrirtæki og markviss pjálfun starfsfólks í að nota pað kerfi sem innleitt var. Sterk tengsl voru milli innleiðingarpátta og pess hvort kerfin sem verið var að innleiða póttu notendavæn eða ekki.

Niðurstöður Jónellu Sigurjónsdóttur (2010), sem rannsakaði hvort innleiðingarferli RSSK hefði áhrif á viðhorf starfsfólks gagnvart peim, voru að innleiðingin hefði áhrif á viðhorf pess. Áhrifapættir voru pátttaka starfsfólks í próun skjalamála, fræðsla starfsfólks um skjalamál og vinnubrögð stjórnenda. Pá kom fram að pegar starfsfólk var virkjað til pátttöku við hönnun kerfisins og tillit var tekið til parfa pess hafði pað hvetjandi áhrif á vinnulag.

Í rannsókn Jóhönnu G. Hafliðadóttur (2010), sem snerist um skjalamál hjá sveitarfélögum, var fjallað um hvaða aðferðir væru árangursríkastar við innleiðingu rafrænnar skjalastjórnunar, hvernig staðið hefði verið að innleiðingunni og hvort skjalastjórar álitu að peir hefðu notið stuðnings stjórnenda við innleiðinguna. Niðurstöðurnar gáfu til kynna að líkur á að innleiðing heppnaðist vel og starfsfólk ynni í kerfinu eins og til var ætlast væru miklar par sem skjalastjóri var virkur í starfi, átti í góðum samskiptum við samstarfmenn, átti auðvelt með að koma efni frá sér í mæltu og rituðu máli og var par að auki ákveðinn og fylginn sér. Pessir pættir vógu pyngra en starfsreynsla og menntun skjalastjóra pó svo að peir pættir skiptu talsverðu máli varðandi innleiðinguna. Pá kom fram að pegar stjórnendur studdu við innleiðinguna og höfðu skilning á innleiðingarferlinu gengu hlutirnir mun betur fyrir sig.

Ýmsar erlendar rannsóknir hafa verið gerðar á innleiðingu á RSSK og notkun peirra. Sem dæmi má nefna rannsókn Gregory (2005) sem snerist um innleiðingu á slíku kerfi hjá National Health Service Purchasing and Supply Agency í Bretlandi. Lögð var áhersla á mikilvægi pess að stigin væru fjögur skref í innleiðingarferlinu; (1) að undirbúa innleiðingarferlið vel, (2) að vinna pá vinnu sem parf í kerfinu við innleiðinguna pannig að kerfið verði notendavænt, (3) að setja saman prófunarhóp til pess að prófa kerfið og fá par með fram gagnrýni pannig að endurbæta og aðlaga megi kerfið og loks (4) að meta árangur innleiðingarinnar. Í rannsókn Gregory (2005) kom fram að sýnilegur stuðningur stjórnenda í innleiðingarferlinu væri nauðsynlegur.

Í rannsókn sinni fjallaði Maguire (2005) um helstu vandamál sem upp geta komið við innleiðingu á RSSK. Hún tiltók raunveruleg dæmi allt frá kaupum á kerfi til notkunar og til pjálfunar starfsfólks. Helstu niðurstöður hennar voru pær að prátt fyrir viðamikla pjálfun náðu fæstir starfsmannanna tökum á kerfinu. Peim pótti kerfið ónotendavænt, peir kvörtuðu yfir uppsetningu tiltekinna pátta í kerfinu og flóknum reglum. Rannsóknin er gott tæki fyrir pá sem hafa í hyggju að innleiða RSSK pannig að hægt verði að forðast mistök pegar verið er að innleiða slíkt kerfi.

Williams (2005) kannaði hvort markmið og fyrirhugaður ávinningur hefðu náðst við innleiðingu á RSSK. Rannsóknin átti sér stað á landsvísu hjá National Weights and Measures Laboratory í Bretlandi, stofnun sem heldur utan um áreiðanleika mælinga og mælikvarða. Par er pví lýst hvernig gekk að innleiða RSSK og leitast við að svara pví hvort væntingar hefðu staðist og árangur náðst með tilliti til pess sem til var ætlast í upphafi. Vel gekk að innleiða kerfið, árangur var góður og notkunin mikil. Hjá stofnuninni var pess krafist að skjalastjórar tileinkuðu sér aðferðafræði breytingarstjórnunar. 


\section{4 Аðferð}

Megindleg aðferðafræði var notuð við framkvæmd rannsóknarinnar. Við úrvinnslu gagna var stuðst við lýsandi tölfræði par sem fyrsta skrefið var að ná fram einfaldri lýsingu á niðurstöðum. Á pann hátt var fundið út hvað dæmigert var í rannsókninni og hve miklu munaði á afstöðu svarenda til mismunandi pátta í úrtakshópnum (Amalía Björnsdóttir, 2003). Spurningalisti með 19 spurningum auk bakgrunnsspurninga var útbúinn. Spurningarnar 19 byggðu á átta prepa líkani Kotters (1996) - sjá viðauka I. Spurningalistinn var settur upp samkvæmt fimm punkta Likert-kvarða, (5) mjög sammála (4) frekar sammála, (3) hvorki sammála né ósammála, (2) frekar ósammála og (1) mjög ósammála.

Pá var notast við svokallaðan Gallup-kvarða í rannsókninni við mat á svörum par sem tiltekin fullyrðing með meðaltalið á bilinu 4,20 - 5,00 telst vera á styrkleikabili, 3,70 - 4,19 á starfhæfu bili og 1,00 - 3,69 á aðgerðarbili. Pegar fullyrðing mælist á aðgerðarbili eru líkur á að sá páttur (í pessu tilviki í innleiðingarferli á rafrænu skjalastjórnunarkerfi (RSSK), sjá töflu 1) hafi ekki gengið nægjanlega vel. Pegar hún mælist á starfhæfu bili hefur hvorki gengið vel né illa. Hins vegar pegar fullyrðing mælist á styrkleikabili gefur pað til kynna að vel hafi gengið með pá pætti í innleiðingarferlinu (Auður Hermannsdóttir og Sif Cortes, 2012).

Pátttakendur voru valdir með pað fyrir augum að ná til sem flestra starfandi skjalastjóra hér á landi. Haft var samband við Félag um skjalastjórn og beðið um aðgang að starfandi skjalastjórum. Félag um skjalastjórn býr yfir netfangaskrá með netföngum langflestra skjalastjóra og peirra einstaklinga sem starfa við skjalastjórnun hérlendis. Formaður félagsins gaf leyfi fyrir pví að könnunin yrði send til skráðra félaga á póstlistann skjalastjorn@listar.ismennt.is. Pegar rannsóknin var gerð voru alls 244 félagar skráðir á póstlistann. Segja má að allir skráðir félagsmenn Félags um skjalastjórn hafi verið pýði rannsóknarinnar og peir fengu allir tölvupóst með tengli á könnunina. Í pessari rannsókn var úrtakið pví pað sama og pýðið. Alls 128 einstaklingarnir hófu að svara spurningalistanum en 88 luku við að svara honum. Svarhlutfallið var 36,1\%. Ekki er gott að segja hvers vegna svörunin var ekki betri. Gera má ráð fyrir að einhverjir sem voru á pessum lista hafi verið hættir störfum. Prátt fyrir petta svarhlutfall má segja að pátttakendur sem svöruðu könnuninni séu góðir fulltrúar pýðisins par sem 65 skjalastjórar af peim 88 sem svöruðu höfðu tekið beinan pátt í innleiðingu RSSK. Baruch og Holtom (2008) segja að algengt svarhlutfall í akademískum rannsóknum sé á bilinu 35\% til 40\%. Saunders, Lewis og Thornhill (2012) greina frá pví að samkvæmt peirra rannsóknum sé algengt svarhlutfall póstkannana á bilinu $10 \%$ til $20 \%$. Könnuninni var beint til einstaklinga sem störfuðu við skjalastjórnun og höfðu átt pátt í pví að innleiða RSSK. Í samræmi við lög um persónuvernd og meðferð persónuupplýsinga, nr. 77/2000, var framkvæmd könnunarinnar tilkynnt til Persónuverndar 26. febrúar 2013. Hún var heimiluð samanber tilkynningu nr. S6189/2013 um vinnslu persónuupplýsinga.

Prír einstaklingar, upplýsingafræðingar sem höfðu unnið við RSSK um langt skeið, lásu spurningalistann yfir. Gagnlegar ábendingar bárust frá peim um sumt sem betur mátti fara og spurningalistanum var breytt lítillega áđur en hann var sendur til pátttakenda. Pórólfur Pórlindsson og Porlákur Karlsson (2003) benda á að forprófun spurningalista stuðli að föngun pess sem kynni að vera ópægilegt, ekki nægjanlega skýrt eða ekki við hæfi. Á pann hátt sé hægt að ná fram pví sem mögulega væri takmarkandi við hönnun og miðlun spurningalistans og bregðast við pví. Könnunin var send með tölvupósti á póstlista Félags um skjalastjórn hinn 4. mars 2013. Hún stóð yfir í átta daga og á peim tíma var ítrekun send prisvar sinnum.

Rannsóknarspurningin var eftirfarandi: Hvert er viðhorf íslenskra skjalastjóra sem hafa tekið pátt í innleiðingu RSSK til innleiðingarferlisins? 


\section{$5 \quad$ Niðurstöður}

Af peim skjalastjórum sem tóku pátt í spurningakönnuninni voru konur 73 eða 92,4\% og karlar sex talsins eða 7,6\%. Enginn pátttakenda var yngri en 25 ára, einn var á aldrinum 26-30 ára og fjórir á aldrinum 31-35 ára. Aldursdreifingin sýnir að tæplega 94\% pátttakenda var eldri en 36 ára og einn af hverjum fjórum eldri en 56 ára. Flestir svarenda höfðu háskólapróf eða um 85\%, $5 \%$ voru með framhaldsskólapróf, 3,8\% með gagnfræða-/verslunar- eða samvinnuskólapróf og 6,2\% merktu við annað. Tæplega 30\% pátttakenda voru með meistaragráðu. Langflestir eða 71,9\% peirra sem höfðu háskólamenntun voru með menntun á sviði félags- og/eða hugvísinda. Af peim sem svöruðu voru 28 eða 35\% með MA/MS eða sambærilega háskólagráðu á sviði skjalastjórnunar. Áhugavert er að skoða starfsheiti peirra sem sinna verkefnum skjalastjórnunar. Раð getur gefið vísbendingar um umfang og eðli starfsins. Flestir báru starfsheitið skjalastjóri (35), pví næst koma starfsheitin sérfræðingur (8), skjalavörður (5) og skjala- og upplýsingastjóri (2). Önnur starfsheiti sem voru nefnd eru héraðsskjalavörður, bókasafns- og upplýsingafræðingur, sviðsstjóri, skjala- og upplýsingastjóri, sérfræðingur skjala- og upplýsingamála, verkefnastjóri, pjónustu- og upplýsingastjóri, deildarstjóri, upplýsingastjóri, sérfræðingur í skjala- og gagnamálum, skrifstofustjóri, ráðgjafi, vef- og skjalastjóri og rekstrarstjóri skrifstofu.

Í rannsókninni var einnig spurt hversu lengi pátttakendur hefðu starfað við skjalastjórnun. Hér er um reynslumikinn hóp að ræða, 57 eða um 65\% pátttakenda höfðu starfað lengur en sjö ár í faginu og 14 eða tæplega 16\% höfðu priggja ára eða skemmri starfsreynslu í skjalastjórnun.

Pátttakendur voru beðnir um að taka afstöðu til innleiðingarferlis rafræns skjalastjórnunarkerfis (RSSK) og tengingu innleiðingarinnar við breytingarstjórnun. Peir voru spurðir hvort peir hefðu tekið beinan pátt í innleiðingunni. Af peim 87 sem svöruðu spurningunni sögðust 65 eða 74,7\% hafa tekið pátt í henni en 22 eða 25,3\% höfðu ekki tekið pátt. Spurningarnar tóku mið af átta prepa líkani Kotters (1996) eins og fyrr er getið. Um er að ræða 19 fullyrðingar sem pátttakendur tóku afstöðu til varðandi innleiðingu á RSSK. Tafla 1 sýnir meðaltal og staðalfrávik pessara 19 fullyrðinga um pátttöku skjalastjóra í innleiðingu á RSSK. 
Tafla 1. Pátttaka í innleiðingu á rafrænu skjalastjórnunarkerfi (RSSK)

Spurning
Hlutverk mitt var mjög skýrt við
innleiðinguna á RSSK.
Markmiðin að baki innleiðingunni voru skýr
í upphafi.

Æðstu stjórnendur studdu við innleiðinguna og breytingarferlið.

Ég hafði fullt umboð æðstu stjórnenda við innleiðinguna.

Starfsmönnum var gefinn kostur á að koma með tillögur varðandi einstaka pætti í innleiðingarferlinu.

Millistjórnendur studdu breytinguna.

Ég tel að innleiðingin á RSSK hafi heppnast vel.

Ég treysti æðstu stjórnendum til pess að viðhalda peim breytingum sem innleiðing á RSSK felur í sér.

Við innleiðinguna fór af stað skipulagt breytingarferli.

Ég hafði yfirumsjón með innleiðingunni.

Upplýsingamiðlun til starfsmanna var virk og peim haldið upplýstum um innleiðingarferlið.

Ég var mjög vel undirbúin/n til pess að takast á við innleiðinguna.

Starfsmenn upplifðu innleiðinguna sem tækifæri fremur en ógnun.

Breytingarnar mættu andstöðu meðal starfsmanna innan skipulagsheildarinnar.

Ég hafði fengið næga pjálfun og fræðslu fyrir innleiðingu kerfisins.

Viðbrögð starfsmanna voru jákvæð við innleiðingu RSSK.

Stjórnendur sýndu frumkvæði og voru til fyrirmyndir við innleiðinguna.

Skipaður var breytingarstjóri eða breytingarteymi áður en innleiðingin hófst.

Haldið var upp á sigra pegar vissum áföngum var náð við innleiðinguna.

Fjöldi

ldi

56

62

64

57

Lægsta

Lagsta

6

2

1

1

1

$$
1
$$

Hæsta

Med̃


Af pessum 19 atriðum lendir ekkert á styrkleikabili p.e. meðaleinkunn er 4,2 eða hærri. Fimm spurningar lenda á starfhæfu bili p.e. meðaleinkunn er a bilinu 3,70-4,19. Flestir pættir eða 14 lenda á aðgerðabili p.e. meðaleinkunn er á bilinu 1,00 - 3,69. Fullyrðingin um að breytingarnar hafi mætt andstöðu starfsfólks hefur pá skírskotun að lágt meðaltal er jákvætt.

Pátttakendur voru einnig spurðir um hvatann að innleiðingu RSSK. Peir gátu valið um nokkur atriði og máttu merkja við fleiri en eitt atriði. Niðurstöður má sjá í töflu 2.

Tafla 2. Hvati að innleiðingu RSSK.

\begin{tabular}{|l|c|}
\hline Hvati að innleiðingu & $\begin{array}{c}\text { Fjöldi } \\
\text { svara }\end{array}$ \\
\hline Lög og reglugerðir & 49 \\
\hline Gæðamál & 43 \\
\hline Nýjar áherslur & 36 \\
\hline Staðlar & 22 \\
\hline Nýir stjórnendur & 17 \\
\hline Annað & 16 \\
\hline
\end{tabular}

Af pessu má sjá að helsti hvatinn voru lög og reglugerðir, gæðamál og nýjar áherslur. Færri merktu við staðla og nýja stjórnendur. Peir sem merktu við annað gátu tilgreint nánar hver hvatinn hefði verið að innleiðingunni. Svarendur nefndu atriði eins og pörf á kerfi til pess að skrá og halda utan um erindi, breytt rafrænt umhverfi, kerfisbreytingu, kröfu stjórnenda, frumkvæði frá skjalastjóra, endurskipulagningu, sameiningu vinnustaða og sérhannað kerfi.

Pátttakendur voru einnig spurðir hvort fram hefði farið parfagreining vegna innleiðingar á RSSK. Niðurstöður hvað pað varðar má sjá í töflu 3.

Tafla 3. Parfagreining vegna innleiðingar á RSSK

\begin{tabular}{|l|r|r|}
\hline Fullyrðing & Fjöldi svaren da & Hlutfall \% \\
\hline Já & 46 & 63 \\
\hline Nei & 12 & 16,5 \\
\hline Veit ekki & 15 & 20,5 \\
\hline
\end{tabular}

Af peim 73 sem svöruðu spurningunni sögðu 46 já eða 63\%, nei sögðu 12 eða 16,5\%. Alls merktu 15 eða 20,5\% við möguleikann „,veit ekki“. Pá var spurt hvort viðkomandi hefði verið pátttakandi í parfagreiningunni sjá töflu 4.

Tafla 4. Pátttaka í parfagreiningu vegna innleiðingar RSSK

\begin{tabular}{|l|r|r|}
\hline & Fjöldi svar en da & Hlutfall \%o \\
\hline Já & 38 & 55,1 \\
Nei & 28 & 40,6 \\
\hline Veit ekki & 3 & 4,3 \\
\hline
\end{tabular}

Af peim 69 sem svöruðu sögðust 38 eða 55,1\% hafa verið pátttakendur í parfagreiningunni, 28 sögðust ekki hafa verið pátttakendur hvað hana varðaði eða 40,6\% og prír eða 4,3\% voru ekki viss. Pegar pátttakendur voru spurðir hvort peir hefðu tekið pátt í vali 
á RSSK svöruðu 35 af 71 pví játandi eða 49,3\% og 35 neitandi sem er einnig 49,3\%. Einn var ekki viss.

\section{Samantekt og umræður}

Hér að framan hefur verið sýnt fram á að skjalastjórnun er mikilvægt stjórnunarsvið í rekstri stofnana og fyrirtækja. Ábyrgur aðili, skjalastjóri, parf að hafa yfirumsjón með peim pætti í rekstrinum (sjá til dæmis Gunnlaugsdóttir, 2002; Staðlaráðs Íslands, 2005).

Rafræn skjalastjórnunarkerfi (RSSK) eru mikilvæg tæki til pess að halda utan um rafræn skjöl og upplýsingar en svo að pau megi nýtast sem skyldi parf að innleiða pau á skilvirkan hátt (sjá til dæmis Jóhanna Gunnlaugsdóttir, 2007). Við innleiðingu kerfanna er skjalastjóri afar háđur pví hversu virkt starfsfólkið er í innleiðingarferlinu. Virkja parf starfsfólk til pátttöku, halda pví upplýstu um verkefnið á innleiðingartímanum, tryggja að sem flestir séu sáttir við notkun kerfisins og pær breytingar sem upptaka pess hefur í för með sér. Loks er mikilvægt að starfsmenn fái nægjanlega og haldgóða fræðslu um verkefnið og pjálfun í pví kerfi sem verið er að taka í notkun. Skjalastjórar ættu að gegna hlutverki breytingastjóra í innleiðingarferli RSSK en niðurstöður pessarar rannsóknar sýna að svo sé ekki. Rannsóknir sýna að aðferðir breytingarstjórnunar eiga einkar vel við pegar innleiða skal nýtt upplýsingakerfi eins og RSSK og skilvirk innleiðing skiptir sköpum par sem koma skal á kerfisbundinni rafrænni upplýsinga- og skjalastjórnun (Kibby, 2005; Jóhanna Gunnlaugsdóttir, 2007; Williams, 2005).

Til pess að innleiðing breytinga gangi vel fyrir sig er mikilvægt að huga að raunverulegum hvata breytinganna. Mikilvægt er að skynja pörfina fyrir breytingar í upphafi ferlisins. Slíkt getur hjálpað starfsfólki að skilja og sjá pörfina fyrir breytingarnar og nauðsyn pess að taka pátt og liðsinna pannig að innleiðing breytinganna gangi upp (Galpin, 1996; Hiatt, 2006; Kotter, 1996). Stjórnendur purfa að gera sér grein fyrir pörfinni fyrir breytingar og nauðsyn pess að innleiða RSSK. Pess háttar pörf getur skapast bæði innan sem utan stofnunar eða fyrirtækis. Innri pörf er tilkomin svo að stofnun eða fyrirtæki verði starfhæft og ytri kröfur geta snúið að pví að lagabreytingar hafi sett peim ákveðnar verklagsreglur á sviði skjalastjórnunar og pess vegna gert breytingarnar nauðsynlegar (Jóhanna Gunnlaugsdóttir, 2007). Í pessari rannsókn kom fram að hvatinn og pau atriði sem höfðu áhrif á kaup og innleiðingu á nýju RSSK voru einkum lög og reglugerðir, gæðamál og nýjar áherslur í starfseminni.

Ýmsir eru peirrar skoðunar að mikilvægt sé að skjalastjórar taki pátt í parfagreiningu, vali á kerfi og próun og aðlögun kerfisins í innleiðingarferlinu (Goldschmidt, Joseph og Debowski, 2012; Ingveldur Tryggvadóttir, 2003; Jóhanna Gunnlaugsdóttir, 2007; Jónella Sigurjónsdóttir, 2010). Pá er lögð áhersla á pað í ÍST/ISO 15489:2001, staðli um upplýsingar, skjalfestingu og skjalastjórnun, að sérfræðingar í faginu beri ábyrgð á öllum páttum innan skjalastjórnunar, svo sem hönnun, innleiðingu og viðhaldi skjalastjórnunarkerfa ásamt pjálfun notenda kerfanna. Í staðlinum er ábyrgð og stuðningur stjórnenda einnig tíundaður (Staðlaráð Íslands, 2005). Pessi rannsókn leiddi í ljós að í 63\% tilvika hafði parfagreining farið fram vegna innleiðingarinnar og einungis rúmlega helmingur svarenda eða 55,1\% höfðu tekið pátt í henni. Hins vegar hafði tæpur helmingur eða 49,3\% verið pátttakendur í vali á RSSK.

Niðurstöður pessarar rannsóknar sýna að aðeins hluti svarenda taldi sig hafa umboð æðstu stjórnenda til athafna vegna innleiðingarinnar $(3,91)$ og sama má segja um pað hvort peir hefðu haft yfirumsjón með innleiðingunni á RSSK $(3,47)$. Prátt fyrir pað töldu fleiri að innleiðingin hefði heppnast vel $(3,57)$. Рað er mikilvægt að skjalastjóri fái fullt umboð til 
athafna allt innleiðingarferlið. Pá parf hann að vera hafður með í ráðum við val á kerfi og gerður ábyrgur fyrir innleiðingunni (Staðlaráð Íslands, 2005).

Mikilvægt er að skjalastjóri njóti fulls stuðnings æðstu stjórnenda og trausts til leiðsagnar á meðan á innleiðingunni stendur. Rannsóknir sýna að stuðningur stjórnenda er ein forsenda pess að innleiðing RSSK gangi vel (Gregory, 2005, Jóhanna Gunnlaugsdóttir, 2007; Jóhanna G. Hafliðadóttir, 2010; Jónella Sigurjónsdóttir, 2010). Í pessari rannsókn kom fram að skjalastjórar töldu stuðning æðstu stjórnenda $(3,95)$ vera meiri heldur en millistjórnenda $(3,61)$. Einnig töldu peir að hlutverk peirra hefði verið mjög skýrt við innleiðingu á RSSK $(4,01)$ og markmið að baki innleiðingunni hefðu verið skýr í upphafi $(3,97)$.

Skilyrði pess að innleiðing RSSK verði árangursrík er að stjórnendur styðji vel við breytingarferlið, sýni gott fordæmi, séu góðar fyrirmyndir og tileinki sér hið nýja verklag. Раð er mikilvægt að stjórnendur átti sig nægjanlega vel á pví að um ákveðið breytingarferli sé að ræða og par gegni skjalastjórar lykilhlutverki. Við upphaf innleiðingarferlis hefst tiltekið hlutlaust tímabil að mati Bridges (2003). Á meðan á hlutlausa tímabilinu stendur getur komið los á starfsmannahópinn, framleiðni getur dvínað og starfsmannavelta aukist. Lewin (1951) bendir á að mikilvægt sé að huga jafnt að drifkröftum og peim hamlandi kröftum í umhverfinu sem geta haft áhrif á innleiðingarferlið og afstöðu starfsfólks. Slíkt getur átt við pegar verið er að innleiða RSSK.

Pví hefur verið haldið fram að ein helsta ástæða pess að breytingar mistakist sé að stjórnendur haldi tilteknu breytingarferli áfram án pess að selja hugmyndina um mikilvægi breytinganna fyrir skipulagsheildina. Átta prepa líkanið hefur skilað góðum árangri en stíga parf prepin í réttri röð og taka pau öll. Ekki er vænlegt að stytta sér leið með pví að sleppa prepum, pað getur leitt til pess að ferlið mistakist. Áttunda prepið, að festa breytingarnar í sessi innan fyrirtækjamenningarinnar, er einkar mikilvægt (Kotter, 1996; Kotter og Cohen, 2002).

Niðurstöður pessarar rannsóknar sýna að skjalastjórar báru ekki fullt traust til æðstu stjórnenda pegar kom að pví að viðhalda peim breytingum sem innleiðing RSSK fól í sér $(3,55)$ og við innleiðinguna fór ekki af stað skipulagt breytingarferli $(3,47)$. Rannsóknin leiddi í ljós að skjalastjórar höfðu hvorki fengið nægjanlega fræðslu fyrir innleiðingu RSSK né pjálfun í kerfinu sjálfu $(3,16)$. Enn fremur kom fram að stjórnendur sýndu almennt hvorki mikið frumkvæði né voru góðar fyrirmyndir í notkun kerfisins á innleiðingartíma $(3,12)$. Aðrar rannsóknir sýna að allir pessir pættir purfi að vera til staðar eigi innleiðing RSSK að heppnast vel (Gregory, 2005; Jóhanna Gunnlaugsdóttir, 2007; Jóhanna G. Hafliðadóttir, 2010; Jónella Sigurjónsdóttir, 2010; Maguire, 2005; Williams, 2005).

Með erfiðari verkefnum stjórnenda er að hrinda breytingum í framkvæmd og innleiða pær og ein algengasta ástæða pess að illa gengur að innleiða breytingar er andstaða starfsmanna (sjá til dæmis Cummings og Worley, 2005). Sérstaklega getur reynst erfitt að innleiða breytingar ef starfsfólk upplifir pær sem einhvers konar ógnun og ávinningurinn af peim er ekki sýnilegur (Martin og Fellenz, 2010). Pá er mikilvægt að starfsfólk sé haft með í ráðum pegar verið er að innleiða RSSK. Að öðrum kosti kynni starfsfólk að verða neikvætt í garð nýrra vinnubragða (Jóhanna Gunnlaugsdóttir, 2007). Spurningalistinn innihélt fjórar spurningar sem snerust um ofangreind atriði. Í fyrsta lagi var spurt hvort breytingarnar hefðu mætt andstöðu meðal starfsmanna $(3,18)$. Önnur fullyrðingin sneri að pví hvort starfsfólk upplifði innleiðinguna sem tækifæri fremur en ógnun $(3,22)$. Priðju fullyrðingunni var ætlað að gefa vísbendingu um afstöðu starfsmanna p.e. hvort viðbrögð starfsmanna væru jákvæð gagnvart innleiðingu á RSSK $(3,15)$. Í fjórða lagi var spurt hvort starfmönnum hefði verið gefinn kostur á að koma með tillögur við innleiðinguna $(3,71)$. 
Í rannsókninni kom fram að ekki var til siðs að halda upp á áfangasigra pegar vissum áföngum var náð í innleiðingarferlinu (2,36). Mikilvægur páttur við að yfirvinna andstöðu starfsfólks er umbun af einhverju tagi. Rannsóknir sýna að pegar starfsfólk er verðlaunað á einhvern hátt tekur pað fúslegar pátt í breytingunum og er líklegra til pess að temja sér breytt vinnulag á jákvæðan hátt. Án umbunar og hvatningar má reikna með að starfsfólk gefist upp við að tileinka sér breytingarnar. Notkun og innleiðing á RSSK felur í sér umtalsverða breytingu á verklagi og pess vegna er umbun og hvatning stjórnenda lykilpáttur í innleiðingarferlinu (Jóhanna Gunnlaugsdóttir, 2007).

Rannsóknarniðurstöður benda til pess að upplýsingamiðlun til handa starfsfólki hafi ekki verið nægjanlega virk (3,34). Kotter og Cohen (2002) leggja áherslu á upplýsingagjöf og skortur á henni getur leitt til andstöðu við að tileinka sér breytt verklag (Martin og Fellenz, 2010). Almennt er talið að mikilvægt sé að skipa sérstakan breytingastjóra eða breytingateymi pegar verið er að innleiða breytingar, pað auðveldi allt breytingaferlið (Kotter, 1997). Niðurstöður pessarar rannsóknar sýna að ekki var pessu til að dreifa $(2,51)$.

Aðrar rannsóknir sýna að stuðningur stjórnenda er nauðsynlegur við innleiðingu á RSSK. Pegar hann er til staðar gengur innleiðing slíkra kerfa jafnan betur fyrir sig en ella (sjá til dæmis Jóhanna Gunnlaugsdóttir, 2007; Jóhanna G. Hafliðadóttir, 2010; Jónella Sigurjónsdóttir, 2010; Maguire, 2005).

\section{Lokaorð}

Hér að framan hefur verið fjallað um innleiðingu á rafrænum skjalastjórnunarkerfum (RSSK). Í upphafi var gerð grein fyrir fræðilegum bakgrunni innleiðingar á pess háttar kerfum. Markmið rannsóknarinnar var að skoða viðhorf íslenskra skjalastjóra til innleiðingar rafrænna skjalstjórnunarkerfa (RSSK) og veita pannig innsýn í hlutverk og pátttöku peirra í pví breytingarferli sem slík innleiðing felur í sér. Rannsóknin byggir m.a. á svörum við 19 spurningum par sem tekið er mið af átta prepa líkani Kotters við innleiðingu breytinga eins og sýnt er í viðauka I. Par leggur hún til mikilvægar leiðbeiningar um pað hvernig best er að standa að innleiðingu á RSSK. Rannsóknina má hagnýta til leiðbeiningar pegar kemur að pví að stýra árangursríkri innleiðingu RSSK í fyrirtækjum og stofnunum.

Mikilvægt er að kanna frekar innleiðingu á RSSK á Íslandi og erlendis. Slíkar rannsóknir, par sem skjalastjórar beggja vegna Atlantshafsins tækju pátt, gætu gefið niðurstöðum pessarar rannsóknar meira gildi og sýnt áhugaverðan samanburð milli landa. Rannsóknin getur pannig lagt grundvöll að frekari rannsóknum á Íslandi og erlendis.

Niðurstöður rannsóknarinnar hafa einnig hagnýtt gildi fyrir stjórnendur fyrirtækja á Íslandi sem vilja innleiða eða endurinnleiða RSSK svo og önnur upplýsingakerfi sem taka á í notkun á vinnustöðum. Fræðilegt framlag hennar er að hún varpar ljósi á hverjir eru mikilvægustu innleiðingarpættir til áhrifa á árangur innleiðingarinnar. Pótt rannsóknin hafi verið gerð hér á landi kynni hún einnig að hafa gildi fyrir meðalstór fyrirtæki í Vestur-Evrópu, Norður-Ameríku og Ástralíu par sem vinnustaðamenning hvað varðar störf, samvinnu, samkeppni og stjórnunarstíl er ekki svo frábrugðin í peim heimshlutum. Í viðauka fylgir gátlisti sem byggir á átta prepa líkaninu og getur hjálpað peim skjalastjórum sem standa frammi fyrir innleiðingu RSSK. 


\section{Heimildir}

Alfa Kristjánsdóttir. (2000, 29. september). Rafræn skjalastjórnun; hvað er pað? Morgunblaðið. Sótt 21. mars 2015 af http://www.mbl.is/mm/gagnasafn/grein.html?grein id=561788.

Amalía Björnsdóttir. (2003). Útskýringar á helstu tölfræðihugtökum. Í Sigríður Halldórsdóttir og Kristján Kristjánsson (ritstjórar.), Handbók i aðferðafræði og rannsóknum i heilbrigðisvísindum (bls. 115-129). Akureyri: Háskólinn á Akureyri.

Armstrong, M. (2012). Armstrong's handbook of human resource management practice (12. útgáfa). London: Kogan Page.

Auður Hermannsdóttir og Sif Cortes. (2012). Vinnustaðamenning við upphaf sameiningar tveggja grunnskóla. Institute of business research - Working paper series, 12 (1), 1-37. Sótt 21. mars 2015 af http://ibr.hi.is/sites/ibr.hi.is/files/WP/audur_sif.pdf.

Baruch, Y. og Holtom, B. C. (2008). Survey response rate levels and trend in organizational research. Human Relations, 61, 1139-1160.

Beckhard, R. (1969). Development: Strategies and models. Reading, MA: Addison-Wesley.

Beckhard, R. og Harris, R. T. (1987). Organizational transitions: Managing complex change. Reading, MA: Addison-Wesley.

Bridges, W. (2003). Managing transitions: Making the most of change (2. útgáfa). Cambridge: Perseus Publishing.

Carnall, C. A. (2003). Managing change in organizations. London: Prentice Hall.

Cumming, T. G. og Worley, C. G. (2005). Organization development and change (8. útgáfa). Thomson: Southwestern.

Drucker, P. F. (2001). Management challenges for the 21st century. New York, NY: HarperBusiness.

Félag um skjalastjórn - IRMA. (2008). Um félagið. Sótt 21. mars 2015 af http://www.irma.is.

Galpin, T. J. (1996). The human side of change: A practical guide to organization redesign. San Francisco, CA: Jossey-Bass Inc. Publishers.

Goldschmidt, P.; Joseph, P. og Debowski, S. (2012). Designing an effective EDRMS based on Alter's Service Work System model. Records Management Journal, 22(3), 152-169.

Gregory, K. (2005). Implementing an electronic records management system: A public sector case study. Records Management Journal, 15(2), 80-85.

Gunnlaugsdóttir, J. (2002). An international standard on records management: An opportunity for librarians. Libri. International Journal of Libraries and Information Services, 52(4), 231-240.

Gunnlaugsdóttir, J. (2012). Information and records management: A precondition for a well functioning quality management system. Records Management Journal, 22(3), 170-185.

Hiatt, J. M. (2006). ADKAR: A model for change in business, government, and our community. Loveland: Proschi Research.

Huy, Q. N. (2001). In praise of middle managers. Harvard Business Review, 79(8), 72.

Ingibjörg Hallbjörnsdóttir. (2007). Skjalastjórn hjá opinberum stofnunum. Bókasafnið, 31, 2226.

Ingveldur Tryggvadóttir. (2003). Skjalastjórn sveitarfélaga. Bókasafnið, 27, 29-32.

Jóhanna Gunnlaugsdóttir. (2006). Skjöl og skjalastjórn í tíu púsund ár. Bókasafnið, 30, 45-57.

Jóhanna Gunnlaugsdóttir. (2007). Svo uppsker sem sáir: innleiðing og notkun á rafrænum skjalastjórnarkerfum. Stjórnmál og stjórnsýsla - Veftímarit, 2(3), 179-209. Sótt 11. desember 2015 af

http://skemman.is/stream/get/1946/8918/23750/1/a.2007.3.2.4.pdf. 
Jóhanna Gunnlaugsdóttir og Kristín H. Pétursdóttir. (1998). Félag um skjalastjórn tíu ára. Bókasafnið, 22, 6-7.

Jóhanna G. Hafliðadóttir. (2010). „Maður verður bara að vera ákveðinn“: Innleiðing skjalastjórnar hjá sveitarfélögum (Óbirt MLIS-ritgerð). Háskóli Íslands, Félags- og mannvísindadeild.

Jónella Sigurjónsdóttir. (2010). „Maður parf að sjá tilganginn“: Viðhorf og parfir ríkisstarfsmanna gagnvart skjalamálum (Óbirt MLIS- ritgerð). Háskóli Íslands, Félags- og mannvísindadeild.

Kibby, P. (2005). The competition commission's story: A case study in EDRM delivery. Records Management Society Bulletin, 125(April), 41-43.

Kolb, D. A. og Frohman, A. L. (1970). An organization development approach to consulting. Sloan Management Review, 12 (Fall), 51-64.

Kotter, J. P. (1996). Leading change. Boston: Harvard Business School Press.

Kotter, J. P. (2005). Change leadership. Leadership Excelence, 22(12), 3.

Kotter, J. P. og Cohen, D. S. (2002). The heart of change: Real-life stories of how people change their organizations. Boston: Harvard Business School Press.

Kristín H. Pétursdóttir. (1988). Skjala- og upplýsingastjórn. Bókasafnið, 11-12, 52-54.

Lewin, K. (1947). Frontiers in group dynamics: Concept, method and reality in social science; Social equilibria and social change. Human Relations, 1, 5-41.

Lewin, K. (1951). Field theory in social science. New York: Harper \& Row.

Lög um persónuvernd og meðferð persónuupplýsinga nr. 77/2000.

Magnea Davíðsdóttir. (2013). "Маður verður að markaðssetja sig“: Hlutverk skjalastjóra í breytingaferli við innleiðingu á rafrænu skjalastjórnunarkerfi (Óbirt MA-ritgerð). Háskóli Íslands, Félags- og mannvísindadeild.

Maguire, R. (2005). Lessons learned from implementing an electronic records management system. Records Management Journal, 15(3), 150-157.

Martin, R. F. og Fellenz M. R. (2010). Organizational behaviour and management (4. útgáfa). Hampshire: Cengage Learning EMEA

Palmer, I., Dunford R. og Akin, G. (2009). Managing organizational change: A multiple perspectives approach. New York: McGraw-Hill.

Read, J. og Ginn, M. A. (2007, 2011). Records management. (9. útgáfa). International Edition: South-Western, Cengage Learning.

Saffady, W. (2011). Records and information management: Fundamentals of professional practice (2. útgáfa). Overland Park: ARMA International.

Saunders, M., Lewis, P., og Thornhill, A. (2012). Research methods for business students. Harlow: Pearson.

Schein, E. H. (2004). Organizational culture and leadership (3. útgáfa). San Francisco: Jossey-Bass.

Senior, B. og Fleming, J. (2006). Organizational change (3. útgáfa). Harlow: Prentice Hall.

Staðlaráð Íslands (2004). ÍST EN ISO 14001:2004: Umhverfisstjórnunarkerfi - kröfur ásamt leiðsögn um notkun. Reykjavík: Staðlaráð Íslands.

Staðlaráð Íslands (2005). ÍST ISO 15489-1:2001: Upplýsingar og skjalfesting - skjalastjórn - 1. hluti: Almenn atriði. Reykjavík: Staðlaráð Íslands.

Staðlaráð Íslands (2006). ÍST ISO/IEC 27001:2005: Upplýsingatækni - öryggistækni - stjórnkerfi upplýsingaöryggis - kröfur. Reykjavík: Staðlaráð Íslands.

Staðlaráð Íslands (2008). ÍST EN ISO 9001:2008: Gæðastjórnunarkerfi - kröfur (4. útgáfa). Reykjavík: Staðlaráð Íslands, 2008.

Williams, D. (2005). EDRM Implementation at the National Weights and Measures Laboratory. Records Management Journal, 15(3), 58-66. 
Pórólfur Pórlindsson og Porlákur Karlsson. (2003). Um úrtök og úrtaksaðferðir. Í Sigríður Halldórsdóttir og Kristján Kristjánsson (ritstjórar), Handbók i aðferðafræði og rannsóknum í heilbrigðisvísindum (bls. 51-66). Akureyri: Háskólinn á Akureyri. 


\section{Viðauki I}

Innleiðing á rafrænu skjalastjórnunarkerfi (RSSK) út frá átta prepa líkani Kotter (1996).

\section{Skynja pörfina fyrir breytingar:}

Hér parf að gera grein fyrir poí af hverju verið er að fara í innleiðingarferli. Hjálpa parf starfsfólki til pess að skilja og sjá pörfina fyrir breytingarnar og mikilvægi pess að bregðast skjótt við og taka pátt. Hvetja parf starfsfólk áfram í breytingarferlinu. Gera parf starfmönnum grein fyrir hoatanum hvort sem раð eru lög og reglugerðir, innri eða ytri pættir eða annað sem kallar á breytingarnar og að breytingin sé óhjákvæmileg.

\section{Mynda leiðbeinandi bandalag sem drífur breytingarnar áfram:}

Mynda parf sterkan hóp sem leiðir breytingarnar. Nauðsynlegt er að stofna stýrihóp eða innleiðingarteymi, öfluga liðsheild sem hefur pekkingu og áhuga. Einstaklingarnir purfa að vera með rétt hugarfar, leiðtogahæfileika, samskiptahæfni, hafa umboð til athafna til pess að hrinda breytingum í framkvæmd og skynja og skilja pörfina fyrir innleiðingunni.

\section{Skapa skýra framtíðarsýn og markmið:}

Virkja parf starfsmenn í breytingarferlinu við að móta nýtt verklag. Deir purfa að gera sér grein fyrir poí hver markmiðin eru og hvernig innleiðingin og breytingin munu skapa nýja framtíð fyrir skipulagsheildina og starfsfólkið allt.

\section{Miðla breytingarsýninni:}

Gera parf starfsfólki ljóst hver framtíðarsýnin er og að með skýrari sýn eru meiri líkur á að innleiðingin og breytingin gangi eftir. Miðla parf breytingarsýninni til starfsmanna á skýran og einfaldan hátt. Halda parf starfsfólki upplýstu um innleiðingarferlið og framgang innleiðingarinnar á hverjum tíma.

\section{Virkja starfsfólkið í breytingum og tryggja víðtækt umboð til athafna:}

Nauðsynlegt er að virkja starfsfólk í innleiðingarferlinu og breytingunum. Á meðan verið er að innleiða nýjar breytingar parf að fyrirbyggja og sigrast á hindrunum. Hafa parf í huga venjur og siði. Hvetja parf starfsmenn til stuðnings við nýtt vinnulag og til jákvæðra athafna.

\section{Búa til og fagna áfangasigrum:}

Skapa parf tækifæri til pess að halda upp á áfangasigra í innleiðingarferlinu og á leiðinni að nýrri framtíðarsýn, breyttu vinnulagi og settum markmiðum eins fljótt og auðið er. Fagna parf hverjum peim áfanga sem hefst með innleiðingunni. Hér er gott að umbuna starfsmönnum fyrir vel unnin störf og fagna með skýrum hætti svo að hvatinn að faglegum vinnubrögðum myndist.

\section{Meta árangur, móta nýjar breytingar og nýta ávinning til enn meiri breytinga:}

Hafa parfí huga að innleiðing á RSSK er langhlaup. Ekki má sofna á verðinum og auðvelt er að fara í gamla farið aftur. Stöðugt parf að vinna i pví að viðhalda breytingum, festa pær í sessi og byggja ofan á pær. Nauðsynlegt er að meta árangur og koma á mælingum um notkun kerfisins og virkja starfsmenn til pátttöku. 


\section{Festa breytingarnar í menningunni:}

Að lokum parf að skapa nýja siði, venjur og viðhorf. Halda parf í nýja hegðun pangað til nýtt atferli og vinnulag er orðið að veruleika og komið i staðinn fyrir gamlar venjur. Nýjar aðferðir eru lengi að öðlast sess og hætta er á að starfsmenn taki upp gamalt vinnulag. Dví er nauðsynlegt að innleiða nýjar aðferðir, nýja ferla, ný viðhorf og nýjar venjur og segja má að innleiðingu á RSSK sé ekki lokið fyrr en kominn er sampykktur gæðaferill um verklagið. 